\title{
Skrivehandlinger og andre handlinger: Design av skriveoppgaver i lærerutdanninga
}

\author{
Ingunn Ofte og Hildegunn Otnes \\ NTNU, Norges teknisk-naturvitenskapelige universitet, Norge
}

\begin{abstract}
Studenter i lærerutdanninga forventes å skrive fagdidaktiske tekster på akademisk nivå. I opplæringa av lærerstudentene som akademiske skrivere blir dermed designet av skriveoppdragene viktig, og det er avgjørende hvor presist selve skriveinstruksen er formulert. Artikkelen presenterer en kvalitativ case studie av in fagdidaktiske oppgaver fra tolv fagdisipliner og tre lærerutdanningsløp ved en norsk lærerutdanningsinstitusjon. Med utgangspunkt $\mathrm{i}$ en forståelse av skriving som en aktivitet utført for visse formål, har vi tatt for oss verbene faglærerne bruker i skriveinstruksene for å indikere ønskede handlinger. Vårt forskningsspørsmål er: Hvilke handlinger blir lererstudenter bedt om å utføre $i$ arbeidet med fagdidaktiske skriveoppgaver?

Analysen viser at studentene blir bedt om å utføre skrivehandlinger på akademisk nivå, men også andre type handlinger knyttet til skriveaktiviteten, både av kognitiv og av mer praktisk art, som er spesifikt retta inn mot lærerprofesjonen. Videre viser analysen at valg av verb er viktig med tanke på tydelighet i oppgaveinstruksene. Vi ser også at visse handlinger er særlig interessante og utfordrende. Især gjelder dette «å reflektere», og vi spør oss om det er en samforent forståelse av dette verbet blant faglærere i lærerutdanninga. Funnene indikerer at det er viktig å rette oppmerksomheten mot hvilke handlinger som skal vektlegges i en fagdidaktisk skriveoppgave i lærerutdanninga og en felles forståelse av hva disse innebærer.
\end{abstract}

Nøkkelord: skrivehandlinger, skriveoppdrag, oppgavedesign, lærerutdanning

\section{INTRODUKSJON}

Studenter i høyere utdanning gjennomgår det Lea og Street (2000) kaller en akademisk sosialiseringsprosess. I denne prosessen tilegner de seg det akademiske fellesskapets måter å forstå og organisere kunnskap på. Ikke minst utvikles evnen til å uttrykke seg i tråd med gjeldende konvensjoner i høyere utdanning. Dette innebærer å kunne analysere, diskutere og anvende faglig kunnskap skriftlig. Forskning viser at å beherske den akademiske diskursen er avgjørende for studenters prestasjoner og progresjon, og en nøkkel til suksess i høyere utdanning (Erixon \& Josephson, 2017; French, 2018). For lærerstudentene innebærer en slik sosialiseringsprosess å lære seg å skrive tekster som tilfredsstiller de allmenne kravene til akademisk skriving samtidig som de viser praktisk og teoretisk kompetanse når det gjelder planlegging og utføring av undervisning. Det er denne kombinasjonen av praksiserfaringer, teoriske tilnærminger og profesjonsfunderte vurderinger som kjennetegner fagdidaktikken som fagfelt (Hertzberg, I999; Lorentzen et al., I998; Sjøberg, 200I). Et sentralt aspekt i opplæringa av lærerstudenter som akademiske skrivere blir dermed å legge til rette for at de utvikler den kunnskapen og de ferdigheter som er nødvendige for å tenke fagdidaktisk og å skrive fagdidaktiske tekster på akademisk nivå.

*Författarkontakt: ingunn.ofte@ntnu.no

Artiklar och reflektioner är kollegialt granskade. Övriga bidragstyper granskas av redaktionen. Se https://hogreutbildning.se ISSN 2000-7558

(C)2021 Ingunn Ofte \& Hildegunn Otnes. This is an Open Access article distributed under the terms of the Creative Commons Attribution 4.0 International License (https://creativecommons.org/licenses/BY/4.0/), allowing third parties to share their work (copy, distribute, transmit) and to adapt it, under the condition that the authors are given credit, that the work is not used for commercial purposes, and that in the event of reuse or distribution, the terms of this license are made clear

Citation: Ofte, I. \& Otnes, H. (2021). «Skrivehandlinger og andre handlinger: Design av skriveoppgaver i lererutdanninga», Högre utbildning, 11(3), 49-66. https://doi.org/10.23865/hu.v11.2832 


\section{Ingunn Ofte \& Hildegunn Otnes}

Et viktig redskap i denne opplæringa er skriveoppgavene studentene får i de ulike fagene, og dermed blir designet av disse svært viktig. Å designe oppgaver krever både bevissthet og kompetanse hos de som formulerer oppgaver. I vår sammenheng er dette lærerne i de respektive fagene, og vi vil iblant bruke benevnelsen «oppgavedesignere» om disse. Det er mange aspekt som skal ivaretas og kommuniseres tydelig til studentene, og skriveoppgaven bør ha en klar og tydelig struktur. Videre må man bestemme hva slags - og hvor omfattende - informasjon man skal ta med, for eksempel om sjanger eller formål (Otnes, 2015). Det er også avgjørende hvor presist selve skriveinstruksen, altså instruksen om hvordan det skal skrives, er formulert. Dette er en essensiell komponent $\mathrm{i}$ en skriveoppgave da den som regel vil inneholde verb som indikerer hva som skal utføres i selve teksten, for eksempel å forklare, å sammenlikne, å beskrive eller å diskutere. Skriveinstruksen sier altså noe om hvilke skrivehandlinger (Berge et al., 20I6) som forventes.

I denne artikkelen presenterer vi en kvalitativ studie av skriveoppgaver som en gruppe lærerutdannere har gitt sine studenter. Vi har analysert i9 fagdidaktiske skriveoppgaver fra tolv ulike fagdisipliner ved en norsk lærerutdanningsinstitusjon. Det er en tekstanalytisk studie, der vi blant annet har sett på grad av innramming og informasjonsmengde i skriveoppgavene og dels på plasseringen av instruksene som blir gitt. Hovedfokuset vårt ligger imidlertid på de ulike typer handlinger oppgaveteksten ber studentene utføre i forbindelse med teksten de skal skrive, og vi har i den forbindelse sett spesielt på verbene faglærerne bruker for å indikere ønskede handlinger. Her er vi primært opptatt av å studere handlingene knyttet direkte til skrivinga, men vi kartlegger også andre handlinger som oppgavematerialet inviterer til, det være seg av kognitiv eller praktisk art. Vår hovedproblemstilling er: Hvilke handlinger blir lærerstudenter bedt om å utføre i arbeidet med fagdidaktiske skriveoppgaver? Vi vil nærmere bestemt identifisere skriveinstrukser og andre instrukser studentene får og studere innholdsnyanser, tydelighet og kompleksitet i disse. I studien vår vil vi sette fokus på bredden av handlinger - skrivehandlinger og andre - et knippe fagdidaktikere har bedt sine studenter utføre. Gjennom studien ønsker vi å bidra til økt bevissthet rundt og en tverrfaglig diskusjon om hvordan fagdidaktiske skriveoppgaver i lærerutdanninga kan designes.

\section{TIDLIGERE FORSKNING PÅ DESIGN AV SKRIVEOPPGAVER}

Forskning på skriving i høyere utdanning har blant annet undersøkt studenters akademiske skrivekompetanse. Flere studier viser at nye studenter ofte strever i møte med universitetets epistemologi og kravene som ligger i denne når det gjelder akademisk tekstkompetanse i både lesing og skriving (se bl.a. Greek \& Jonsmoen, 20I6; Hellekjær, 2005; Hendricks \& Quinn, 2000). En studie fra svensk førskolelærerutdanning (Arneback et al., 20I6) viste også at studentene ofte opplevde forskjellene mellom ulike fagtradisjoner når det gjaldt krav og forventninger til akademisk skriving som utfordrende, og at dette kunne føre til usikkerhet hos dem.

Mye av den internasjonale forskninga på oppgavedesign i høyere utdanning er fra 1980- og 90-tallet (Brossell, I983; Kroll \& Reid, 1994) og dermed relativt gammel. Et trekk som går igjen, er forsøkene på å klassifisere oppgavene - ut fra innhold, form eller formål. Allerede i 1983 presenterte den amerikanske skriveforskeren Gordon Brossell en tredeling av oppgaver, nemlig oppgaver med «low, moderate and high information load». I oppgaver med høy informasjonsmengde er det gjerne beskrevet en hypotetisk situasjon, et scenario, som skriveren skal inngå i (Brossell, 1983). Han mente å finne at oppgaver med lav informasjonsmengde ga for få føringer og at studentene brukte for stor del av teksten på å snevre seg inn mot det vesentlige, 
mens oppgavene med høy informasjonsmengde ga for mange føringer, og mange følte det som et hinder å bli tvunget inn $\mathrm{i}$ et hypotetisk scenario.

De amerikanske forskerne Barbara Kroll og Joy Reid (1994) presenterer også en tredelt inndeling av skriveoppgaver, denne ut fra hvor mye selve skriveinstruksen er "pakket» inn i informasjon. «Bare prompts», eller nakne oppgaver, gir selve skriveoppdraget i ganske korte og enkle ordelag ved å antyde tema eller stille et spørsmål. «Framed prompts», eller innrammede oppgaver, presenterer en situasjonskontekst før selve skriveinstruksen gis. «Textbased prompts», eller tekstbaserte oppgaver, er oppgaver der utdrag fra autentisk eller tilrettelagt materiell følger oppgaven, og som eleven må lese for å kunne besvare den.

Videre har grad av tydelighet i selve skriveinstruksen blitt viet oppmerksomhet i studier av skriveoppgaver på flere nivå i utdanningssystemet. I sitt doktorgradsarbeid på slutten av 1990-tallet skilte Egil Børre Johnsen (1997) mellom oppgaver med og oppgaver uten eksplisitt instruks. Med instruks mente han at oppgaven opplyser hva slags skriving eleven skal bedrive, og han fant at flere oppgaver i artiumsstil-materialet hans var uten formelle holdepunkter for selve skrivearbeidet. Han kategoriserte for eksempel oppgaver med kun temaangivelse eller et spørsmål som «uten instruks», og mente at det først er når det oppgis «en formell angivelse av skrivehandlingen» at det gis en instruks (Johnsen, 1997, s. 138). Analysene av oppgavematerialet i Normprosjektet ${ }^{\mathrm{T}}$ har fulgt opp dette perspektivet og vektlagt viktigheten av at oppgaveformuleringene er tydelige i sine instrukser om skrivehandlinger (Dagsland, 2018; Otnes, 2014, 2015).

Flere studier i høyere utdanning har fokusert på reflekterende skriving, særlig i en utdanningskontekst, og prøvd å fange hva som kjennetegner det å reflektere (se bl.a. Grüters, 2oII; Søndenå, 2002) og hva det vil si å skrive reflekterende. Ruth Grüters har blant annet i sin gjennomgang av ulike refleksjonsstudier konkludert med at refleksjon er et begrep som «inviterer til, men samtidig synes å yte motstand mot en presis begrepsavklaring» (Grüters, 20II, s. 24). Likevel ser det ut til at det er en viss enighet om at refleksjon ofte omfatter kognitiv aktivitet knyttet til praktiske erfaringer, og gjerne også til personlig utvikling (Dysthe et al., 200o; Korthagen, 20I4; Schön, 1990). Det framheves imidlertid av flere at en slik refleksjon ofte gjøres på et svært overflatisk nivå, og at det må arbeides for å få studenter til å reflektere mer dyptpløyende og høyne kvaliteten på refleksjonen (Korthagen, 2014; Søndenå, 2002).

Enkelte studier ser på i hvilken grad skriveoppdragene legger til rette for studentenes utvikling av kritisk tenkning og refleksjon. For eksempel har Liu og Stapleton (20I5, 20I8) studert skriveoppgaver brukt i engelske språktester i høyere utdanning i Kina. De fant at skriveoppgavene var standardiserte og ensrettede, og dermed ikke la til rette for studentenes utvikling av kognitive ferdigheter, men heller resulterte i oppskriftsmessige og ensartede studentbesvarelser. De etterlyser en større variasjon i skriveoppdragene som legger til rette for utvikling av akademiske ferdigheter generelt, og kritisk tenkning spesielt (20I5).

Studier har også sett på skrivehandlinger i oppgavetekster. I en amerikansk studie av skriveoppgaver gitt til siste års high school-elever poengterer forskerne Beck og Jeffrey (2007) at det er et behov for større konsensus om hva slags skrivehandlinger ulike skriveinstrukser innebærer, og at dette bør komme tydelig fram i oppgaveformuleringene. I Norge har Ingrid Stock og Nancy Lea Eik-Nes (2019) analysert bruken av ulike skrivehandlinger i studenters bacheloroppgaver. De kartlegger i hvilken grad skrivehandlingene er de samme som brukes i forskningsartikler fra

1 Normprosjektet studerte skriving på mellomtrinnet i perioden 2012-2016 (Matre et al., 2020). 
feltet og finner at dette ofte er tilfelle, men at det samtidig er stor variasjon mellom fagfeltene. Basert på dette mener Stock og Eik-Nes at et fokus på skrivehandlinger kan være et viktig bidrag til å utvikle et metaspråk i samtaler mellom veiledere og studenter. Vi vil følge opp dette perspektivet ved å særlig se på verbbruk i fagdidaktiske oppgaver i lærerutdanninga. På denne måten søker vi, gjennom vår studie, å bidra med mer kunnskap om oppgavedesign $\mathrm{i}$ høyere utdanning.

\section{TEORETISKE PERSPEKTIVER}

Med utgangspunkt i vår problemstilling om design av fagdidaktiske skriveoppgaver, finner vi det nødvendig å presentere noen teoretiske perspektiver på skriving så vel som på fagdidaktikk. Innenfor begge disse feltene anser vi handling som et sentralt begrep. Handlinger innebærer formålsretta aktivitet som krever visse kunnskaper og ferdigheter for å utrette noe. I vår sammenheng er altså handlingene knyttet til kunnskaps- og ferdighetsområdene skriving og fagdidaktikk.

\section{Skriving}

Vår studie bygger på en forståelse av skriving som en meningsskapende aktivitet forankret i den sosiale og kulturelle konteksten aktiviteten skjer i (Cremin \& Myhill, 20I2; Ivanič, I998; Lea \& Street, 1998). I slike kontekster vil man mer eller mindre bevisst tilegne seg relevante skrivepraksiser og språklige diskurser ved å delta i sosialt situerte «literacy events» som oppleves som nyttige (Ivanič, 2004). Man tilegner seg altså relevant skrivekompetanse gjennom å delta i praksisfellesskap (Wenger, 1998) hvor man tar del i ulike praksiser og aktiviteter som er karakteristiske for fellesskapet. Gjennom slik deltakelse vil man i økende grad identifisere seg med de verdier, praksiser og aktiviteter som er typiske for deltakerne i disse praksisfellesskapene (Ivanič, 2004).

Et slikt teoretisk ståsted innebærer videre at vi ser på skriving som handlinger utført for visse formål (jf. bl.a. Berge et al., 20I6; Vähäpassi, 1988). Helt konkret manifesterer dette seg i ulike skrivehandlinger som man kan utføre for å oppnå formålet. Dette er blant annet forsøkt visualisert i det såkalte «Skrivehjulet», en modell som inkluderer seks skrivehandlinger (Berge et al., 20I6). ${ }^{2}$ En tekst består ofte av flere skrivehandlinger, men avhengig av hvilke tekstlige element som er i forgrunnen, kan man gjerne oppfatte en skrivehandling som mer «dominant» enn andre (Dagsland, 20I8). Dette gjenspeiles også i skriveoppgaver, da disse ofte ber elever og studenter utføre flere skrivehandlinger i en og samme tekst.

Skriveoppgaven er en egen tekst med sitt eget innhold, sin egen form og sitt eget definerte formål; oppgavedesigneren er altså selv en forfatter (Otnes, 20I5). Ongstad (1997) har også diskutert oppgavetekster som en egen sjanger, i den forstand at slike tekster handler om konvensjoner og forventninger. Selv om form og innhold selvsagt varierer fra oppgave til oppgave, og fra fag til fag, er det en felles forventning om at skriveoppgaver skal gi en instruks eller input av et eller annet slag i den hensikt å få elevene/studentene til å dokumentere, prestere og kommunisere. Dermed mener vi det er relevant å ha en tekstanalytisk tilnærming i studier av oppgavetekster (jf. Johnsen, 1997; Kvistad \& Otnes, 2019; Otnes, 20I4; Troelsen, 2018).

2 De seks skrivehandlingene i Skrivehjulet er: reflektere, beskrive, utforske, forestille seg, overbevise og samhandle. 


\section{Fagdidaktikk}

Fagdidaktikk omfatter læren om undervisning, men begrepet brukes og defineres noe ulikt på tvers av landegrenser og fagkulturer. En definisjon av fagdidaktikk som er blitt gjengitt av mange i norsk lærerutdanning, er den som samfunnsfagdidaktikeren Svein Lorentzen lanserte på 1990-tallet:

Fagdidaktikk er alle de refleksjoner en kan knytte til et fag og undervisning i dette faget, som kan gi økt kunnskap om fagets beskaffenhet, om fagets legitimering og økt kunnskap om hvordan faget kan læres, undervises og utvikles (Lorentzen et al., 1998, s. 7).

Videre har naturfagdidaktikeren Svein Sjøberg omtalt fagdidaktikken som en slags bro mellom faglig innhold og pedagogisk refleksjon (Sjøberg, 200I, s. 2). Han har også beskrevet fagdidaktikk som «overveielser knyttet til undervisning og læring i et fag og til dette fagets situasjon $i$ skole, utdanning og samfunn» (Sjøberg, 20oI, s. 3). Ellers framhever han at fagdidaktikken skal gjøre lærere i stand til å treffe begrunnede valg (Sjøberg, 200I, s. 7).

Norskfagdidaktikeren Hertzberg har også prøvd å nærme seg fagdidaktikkens vesen. Blant annet har hun pekt på at studentene i stor grad etterlyser stoff de kan bruke direkte i praksis, mens faglærerne mener at «målet må være å sette studentene i stand til selv å vurdere hvordan stoffet kan tilrettelegges for undervisning» (Hertzberg, 1999, s. 3I). I definisjonene gjengitt ovenfor, merker vi oss blant annet ord som refleksjon, legitimering, overveiing og valg - handlinger som lærere og lærerstudenter skal gjøres i stand til å kunne gjennomføre og til å begrunne på et akademisk nivå. Fagdidaktikken er med andre ord en akademisk disiplin fundert på praktisk så vel som teoretisk kunnskap.

Selv om fokuset $\mathrm{i}$ vår studie ikke er på det fagdidaktiske innholdet $\mathrm{i}$ oppgavene, men på selve skriveinstruksene, vil materialet likevel kunne avdekke noe om hvordan faglærerne vinkler det fagdidaktiske i sine skriveoppgaver. Dessuten vil vår kartlegging av verb $\mathrm{i}$ analysedelen muligens kunne avdekke om det er noen handlinger som er særlig brukt i denne typen oppgaver.

\section{MATERIALE OG METODE}

Denne artikkelen presenterer en kvalitativ case studie hvor vi har sett på In fagdidaktiske oppgaver fra tolv fagdisipliner ved en norsk lærerutdanningsinstitusjon. Lærerstudenter må skrive ulike typer tekster i løpet av sin utdanning, noen disiplinfaglige og noen profesjonsfaglige (fagdidaktiske). Vi har valgt å ta for oss fagdidaktiske oppgaver fordi disse er vanlige i norsk lærerutdanning og fordi de til en viss grad er sammenliknbare på tvers av faggrenser. Slike oppgaver ber studentene skrive fullstendige, sammenhengende tekster av en viss lengde, og har ofte krav om at praktiske eksempler innrammes av teoretisk fundering, drøftinger og referanser.

Via en henvendelse til de ulike faggruppene fikk vi tilgang til oppgaver fra forskjellige fag ved følgende lærerutdanningsløp: grunnskolelærerutdanninga I-7 og 5-IO (GLU) og lektorutdanninga 8-I3. ${ }^{3}$ Oppgavene er hentet fra I. til 3. år. Ved å inkludere oppgaver fra ulike fag og utdanningsløp ønsker vi en bredde i datamaterialet, med muligheter for å få fram likheter og

3 For detaljert oversikt over fag og fagretninger som inngår i studien, se under Analyser og funn. 


\section{Ingunn Ofte \& Hildegunn Otnes}

ulikheter. Alle oppgavene ble gitt studentene før prosjektets oppstart og inngår enten i det obligatoriske arbeidet i et fag eller som en del av sluttvurderinga i faget, eller begge deler.

Vårt materiale er lite, og bare hentet fra én institusjon. Målet har dermed ikke vært å fastslå noe generelt om fagdidaktiske oppgaver. Vi har i denne studien heller ikke sett på studentbesvarelsene eller tatt med eventuelle muntlige instruksjoner som komplementerte de skriftlige. Dette kunne trolig gjort bildet mer utfyllende, fordi først da ser vi hvordan studentene forstår oppdragene. I denne omgang er vi imidlertid interessert i å se på i hvilken grad vi kan tolke instruksene uten de kontekstuelle dimensjonene.

I analysen er de ulike fagene samlet i faggrupperinger. Kunst og håndverk, kroppsøving og musikk er samlet under praktisk-estetiske fag, mens engelsk, norsk og fremmedspråk er samlet under språkfag. KRLE, samfunnsfag og geografi er samlet under samfunnsfag, mens matematikk, fysikk og biologi er samlet under realfag. Vi har valgt å ikke bruke fagbenevnelser i presentasjonen/analysen da det i noen fag bare er én faglærer som har bidratt med oppgavemateriale. Siden materialet er hentet fra én utdanningsinstitusjon gjør personvernhensyn det problematisk å bruke fagbenevnelser.

Først gir vi en kort deskriptiv analyse av oppgavelengde og struktur. Deretter ser vi på hvilke konkrete instrukser som er gitt - skriveinstrukser eller andre instrukser. Her har vi forsøksvis identifisert og sortert verbene og/eller verbfrasene med utgangspunkt i hva disse sier om ulike handlinger som forventes av studentene. Selv om verbene alene ikke kan si alt om hva som skal skje, er de svært sentrale i beskrivelser av handling, og der det kreves mer informasjon enn selve verbet, tar vi også med slike tillegg.

\section{ANALYTISKE TILNÆRMINGER OG RESULTAT}

En kort beskrivelse av oppgavelengde og struktur

Visuelt sett er den tydeligste forskjellen mellom skriveoppgavene i materialet at de varierer i lengde, fra i underkant av $1 / 2$ side til to sider (se ill. I), og dette skyldes ulikheter i mengden informasjon oppgavetekstene inneholder. Materialet omfatter ingen «nakne oppgaver» (jf. Kroll \& Reid, 1994), altså med bare et spørsmål eller et angitt tema, men noen av oppgavene er ganske knappe og konsise og må sies å ha «moderat» informasjonsmengde (jf. Brossell, 1983). Mange av oppgavene har høy informasjonsmengde fordi de inneholder mye kontekstinformasjon. Dette kan være informasjon relatert til selve skriveprosessen (skriveramme, vurderingskriterier e.l.), til den faglige konteksten (kompetansemål, litterære tekster, pensumlitteratur osv.) og/eller til et spesifikt scenario (en historisk hendelse, en klasseromssituasjon e.l.).

Den ulike mengden kontekstinformasjon medfører blant annet at ulike skrivehandlingsverb som benyttes i oppgaveteksten, ikke nødvendigvis er proporsjonalt med dens lengde. Oppgave 6 og 17 er begge på ca. I,5 side, men inneholder henholdsvis to og seks ulike skrivehandlingsverb (i begge oppgavene gjentas imidlertid noen av verbene). I vårt materiale er det altså ingen automatikk $i$ at lange oppgaver inneholder mange ulike skrivehandlingsverb mens korte oppgaver inneholder få. Dessuten inneholder jo mange av oppgavene også instrukser om andre handlinger enn skriving.

Videre ser vi at det varierer hvor i oppgaven selve skriveinstruksene er plassert. I noen av oppgavetekstene er de plassert først (jf. ill. 2a), mens i andre kommer de på slutten av oppgaveteksten (jf. ill. 2b). I materialet vårt er det også eksempler på oppgaver hvor skriveinstruksene er delt opp og fordelt ulike steder utover i teksten (jf. ill. 2c), noe som bidrar til en større kompleksitet og kanskje gjør det mer utfordrende for studentene å avkode.

I flere av oppgavene benytter faglæreren strukturelle grep som hjelper studenten til å skjønne at noen oppdrag er viktigere enn andre, for eksempel ved å plassere det overordna oppdraget 
Samfunnskunnskap

Oppgave:

Ta utgangspunkt i læreplanene for:

- Ungdomstrinnet:

o Samfunnskunnskap, kompetansemål etter ro.trinn;

- Videregående skole:

o Samfunnsfag fellesfag $\mathrm{vg} / \mathrm{vg} 2$

o Programfagene sosiologi/sosialantroplogi, sosialkunnskap og politikk og menneskerettigheter.

Formuler noen læringsmål og en beskrivelse av undervisningen. Ved å anvende pensum, drøft hvorvidt denne undervisningen er kunnskapsbasert, ferdighetsbasert og/eller holdningsbasert.

- Det er positivt om du trekker inn egne erfaringer fra praksis.

Praksisoppdrag I i Matematikk I

Om praksisoppdraget

Målet med praksisoppdraget er at dere skal begynne å utvikle forskningsog utviklingskompetanse innen matematikkundervisning. Dette innebærer å kunne utforme en problemstilling, tenke over hva en må gjøre for å samle inn data for å svare på problemstillingen, gjennomføre denne undersøkelsen i praksis, og å drøfte funnene opp mot teori/litteratur. Gjennom dette skal dere også utvikle kompetanse i å analysere og vurdere elevers tenkemåter, argumentasjon og løsningsmetoder ut fra matematikkdidaktisk teori.

\section{Rammer}

I den første praksisperioden vil hovedmålet generelt være å bli kjent med klassen og elevene. Vi har derfor ikke lagt opp til at praksisoppdraget skal innebære stor grad av elevinvolvering. Vi ser for oss at selve undersøkelsen i praksis gjøres gjennom en kort samtale ( $5-15 \mathrm{~min}$ ) med en liten gruppe av elever (2-4) eller en enkeltelev, eksempelvis som del av et stasjonsarbeid eller underveis i en undervisnings-/arbeidsøkt for klassen.

Selv om elevinteraksjonen i undersøkelsen skal være av et begrenset omfang, så kreves det grundig planlegging. Undersøkelsen skal reflektere et samspill mellom teori/litteratur og praksis. Et godt samspill mellom teori og praksis innebærer at man

- bruker teori/litteratur til å forstå bedre, analysere og reflektere over noe man har lagt merke til i praksis. Altså, at man bruker den faglige kunnskapen i praksis og at man ser at det er behov for den, at man trenger den i praksis («bruke» vs. «referere til» kunnskapen)

- bruker det man har observert i praksis til å forstå bedre det man har lest og til å reflektere over hva det egentlig kan bety (både rent teoretisk og i praksis), og hva som kan være (videre) utfordringer.

I. Dere skal i grupper på 2-3, utforme en problemstilling som går på elevers arbeid og forståelse innen tall og regning. Det innebærer at dere skal bestemme dere for et område/begrep/sammenheng innenfor dette fagområdet som dere vil undersøke nærmere. På bakgrunn av litteraturen og det vi har jobbet med frem til nå, skal dere utforme et spørsmål.

2. Dere må også planlegge hvordan dere skal finne svar på denne problemstillingen. Det kan være naturlig å tenke seg en samtale med elevgruppa (eller enkelteleven) som tar utgangspunkt i en aktivitet/oppgaver dere lager. En grundig planlegging krever at dere tenker nøye gjennom både valg av aktivitet og momenter som er viktig i selve samtalen (spørsmålsstilling, kommunikasjonsform etc.). Husk at aktivitet og spørsmål skal være utformet slik at de hjelper dere til å få svar på problemstillingen.

Problemstillingen dere utformer i forkant, kan justeres hvis resultatet av datainnsamlingen tilsier at det er ønskelig.

I praksis

Dere skal gjennomføre den planlagte aktiviteten og samtalen, og samle inn data. Dere bør ta opp samtalen og/eller sørge for at en av dere tar notater underveis mens en annen leder samtalen. Avhengig av problemstillingen deres og aktiviteten dere legger opp til, kan det også være relevant å ta en kopi av elevenes skriftlige arbeid.
Eventuelle lydopptak skal transkriberes så raskt som mulig etter gjennomføring, og lydopptaket slettes.

Etter praksis

I undervisningsøkta mandag i uke 39 skal funnene drøftes i grupper. Dere må da kunne gi en presentasjon av problemstillinga og de aktivitetene dere valgte for å belyse denne, presentere et kort utdrag av datamaterialet, og gi en kort analyse av dette ved hjelp av litteraturen vi har jobbet med i emnet. I de fleste tilfeller vil det her være fordelaktig å velge ut de(t) mest interessante elevsvarene, og drøfte dette med litt dybde, istedenfor å gi et resymé av alt som ble gjort og sagt. Tilbakemeldinger og kritikk fra gruppe vil da danne grunnlag for det videre arbeidet.

På bakgrunn av dette skal det skrives en fagtekst som leveres innen fredag 29/9.

Fagteksten skal være et samspill mellom teori og praksis, men det er ikke lett å få til det. Her er noen råd for å få til et godt samspill mellom teori og praksis:

- Prøv å unngå at oppgaven hovedsakelig blir "en fortelling fra praksis"

- Gjør noe grundig, ikke mye overfladisk

- Reflekter over enkeltepisoder heller enn å presentere mange episoder

- Presenter dere mer som forskere enn som fortellere

- Bruk, og reflekter over, relevant teori i forhold til egne funn i praksis. Hvordan kan hoveddelen struktureres, slik at den er leservennlig, og slik at den er en god sammenfletting av observasjoner og teori/litteratur der man bruker litteratur til bedre å forstå praksis, og man bruker praksis til bedre å forstå litteratur?

- Vær nøye med bruk av kilder

Teksten skal ha en kort innledning der dere redegjør for bakgrunnen for deres valg av problemstilling. Hvorfor er problemstillingen interessant å undersøke for en lærer?

I hoveddelen skal dere presentere et utvalg av deres datamateriale, det dere har tenkt å se nærmere på og analysere for å kunne svare på problemstillingen. Observasjonene skal drøftes ved å bruke litteraturen vi har jobbet med i faget og eventuelt annen relevant litteratur. Momenter dere tar opp i drøftingen bør være i klar sammenheng med din problemstilling.

Til slutt skriver dere en kort oppsummering. Hva er dine viktigste funn? Her skal dere også reflektere kort over deres opplevelse av arbeidet med oppdraget - ta gjerne opp hva som har vært spesielt utfordrende/givende i dette arbeidet for dere, hva som har vært overraskende, hva som har fătt dere til å undre på noe - noe om matematikk, noe om det å være matematikklærer?

Tenk over hvordan teksten deres svarer på målet om å utvikle kompetanse $\mathrm{i}$ å analysere og vurdere elevers tenkemåter, argumentasjon og løsningsmetoder ut fra ulik matematikkdidaktisk teori og ulike perspektiver på kunnskap og læring.

Lengden på fagteksten skal være 6-9 sider (eventuelle vedlegg kommer i tillegg). Se også på mer formelle krav når det gjelder fagtekster på ALT: https://innsida.ntnu.no/documents/IoI57/I24399535/ALTs-krav-tilfagtekster.pdf/aa99b230-IIdo- 4ba9-a8a3-Iaoffa8428a3

Illustrasjon I: Eksempler på kort og lang oppgavetekst ${ }^{4}$

${ }^{4}$ Her er ikke poenget å lese innholdet i oppgavene, men å få et inntrykk av omfanget. 


\section{Ingunn Ofte \& Hildegunn Otnes}

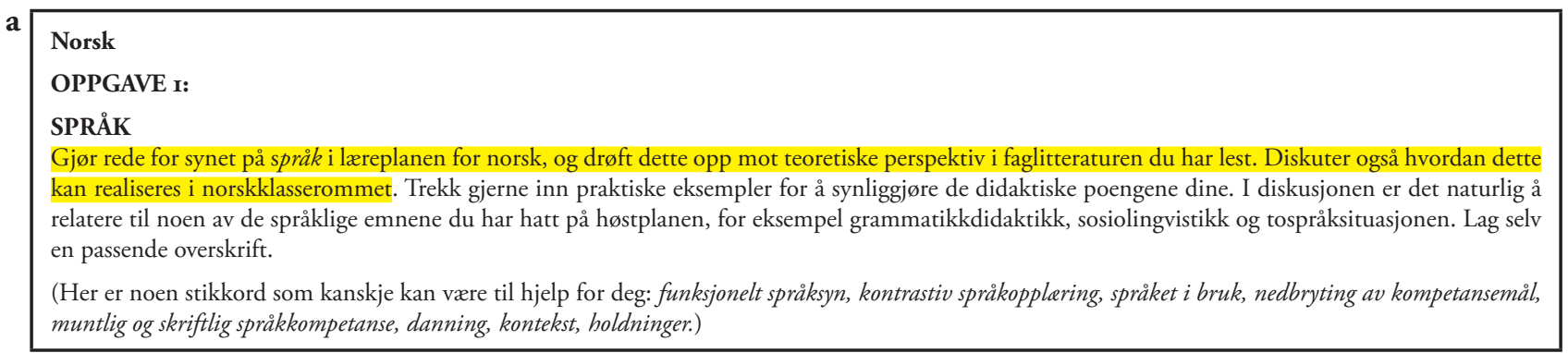

b Geografi

\section{OPPGAVE:}

Ta utgangspunkt i ett av kompetansemålene fra Kunnskapsløftet (2006/2013) (www.udir.no/læreplan):

Enten: Ungdomsskolen: Mål for opplæringa er at eleven skal kunne beskrive og forklare natur- og kulturlandskapet i lokalsamfunnet

Eller: Videregående: Mål for opplæringa er at eleven skal kunne beskrive naturlandskap og forskjellige kulturlandskap og forklare samanhengar og skilnader mellom dei

Du skal lage en plan for klassen din for en dobbeltime med utgangspunkt i ett av kompetansemålene over.

Lag en skisse for hvordan du vil undervise i målet du valgte. Denne bør inneholde spesifikke læringsmål for timene, ulike arbeidsmetoder og en enkel tidsplan for gjennomføring.

Du skal implementere arbeid med en (eller flere) av læreplanens grunnleggende ferdigheter som en del av undervisningsopplegget ditt.

Begrunn og reflekter over valg av undervisningsmetoder/arbeidsmetoder i forhold til relevant teori (trekk inn pensum).

Formuler en fagdidaktisk problemstilling til planen din. Drøft problemstillingen med vekt på begrunnelser og erfaringer (egen praksiserfaring), fagdidaktisk teori og læreplanen.

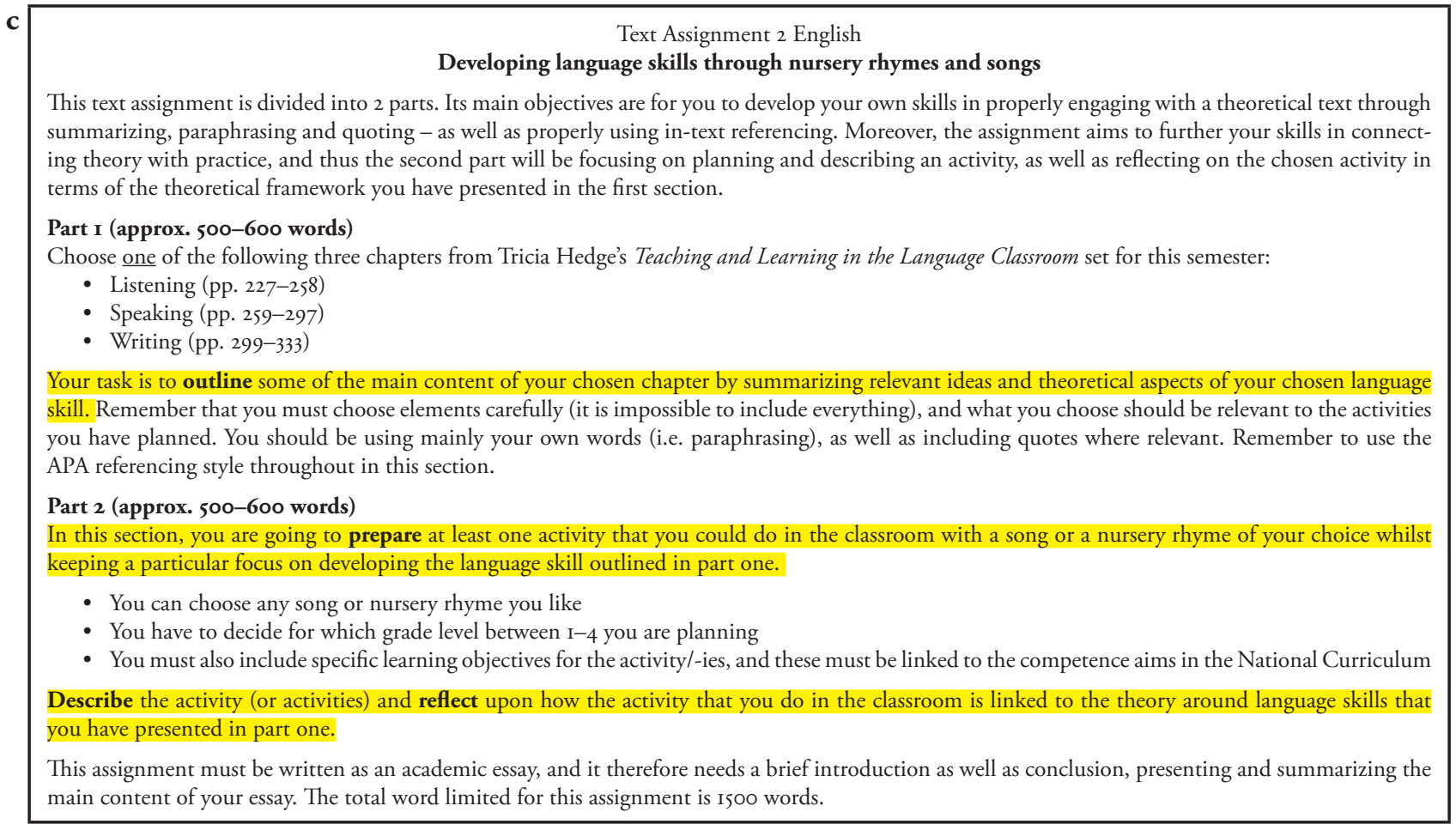

\section{Illustrasjon 2a-c: Skriveinstruksene er markert med gult}

5 Hensikten med disse illustrasjonene er ikke å lese innholdet, men å se hvor i oppgavetekstene skriveoppdraget er plassert. 
tidlig i oppgaveteksten eller ved å markere det med fet skrift, kursiv, eller bruk av farger. I de tilfellene hvor hovedinstruksen framheves i oppgaveteksten, ser vi det som et bevisst grep i oppgavedesignet, og vi mener det kan være en relevant støtte for studenten.

\section{Skrivehandlinger og andre handlinger}

I hovedanalysen ønsket vi å identifisere og sortere instruksene og studere anvendelsen av dem i oppgaveteksten. Dette ble gjort ved å markere alle verb (inklusive verbfraser og nominaliseringer av verb) ${ }^{6}$ som initierte de handlingene studentene skulle utføre. Etter flere runder med materialet kom vi fram til to hovedkategorier: I) verb knyttet til skriveaktiviteten og 2) verb som angir andre handlinger. Den første hovedkategorien ble så delt inn i to underkategorier: verb som angir skrivehandlinger (jf. Skrivehjulet) og andre verb knyttet til skrivinga (se tabell nedenfor). Disse kategoriene har ikke vanntette skott, og vi problematiserer derfor dette nedenfor. Denne kategoriseringen inngår som en del av analyseprosessen, og er ikke en endelig taksonomi. Et eksempel som kan belyse slike nyanser i kategoriseringa er når studentene skal «ta utgangspunkt i» eller «trekke inn» faglitteratur, da det her kan være forskjell på om de skal lese og få ideer forut for skrivinga (høyre kolonne), eller om de skal skrive det inn i selve teksten (midtre kolonne). Ellers kan nevnes at selv om det én oppgavetekst er brukt det samme verbet flere ganger, er dette bare notert én gang i tabellen.

Del 1: Skrivehandlinger

Som forventet inneholder alle skriveoppgavene instrukser knyttet direkte til skrivinga. Dette er instrukser som forteller studentene hvordan de skal skrive, for eksempel om de skal beskrive, drøfte eller begrunne. Vi har kalt disse verb som angir skrivehandlingen (jf. venstre kolonne i tabellen). I disse tilfellene er det, stort sett, tydelig hvilken skrivehandling det legges opp til - eller at det $i$ alle fall er verb som er kjente skriveinstrukser i akademia. Vi ser også at antall verb som angir skrivehandlinger varierer mellom oppgavene, fra seks (oppg. I7) til ett (oppg. 6, I4 og 19). De skrivehandlingsverbene i denne kategorien som forekommer i flest oppgaver, er drofte (9 oppgaver), diskutere (4 oppgaver), beskrive (5 oppgaver), reflektere (6 oppgaver), begrunne (7 oppgaver) og redegjørel gjøre rede for (6 oppgaver).

Videre inneholder I5 av I9 oppgaver også instrukser vi har kalt andre verb knyttet til skrivinga (midterste kolonne i tabellen). Dette er instrukser som er relatert til selve skrivearbeidet, for eksempel belyse, vise og peke $p a ̊$, men som ikke umiddelbart sier noe om hva slags skriving instruksen innebærer. Egil Børre Johnsen (I997), i sine studier av artiumsoppgaver, regnet heller ikke formuleringer med slike verb som eksplisitte skriveinstrukser, da de ikke sier noe om selve skriveaktiviteten. Det kan selvsagt diskuteres hvor grensa mellom verbene i venstre og midtre kolonne går i en del sammenhenger, og vi har derfor markert grensa mellom dem med en stiplet linje. Vi har for eksempel plassert verb som presentere og introdusere i den midterste kolonna, selv om andre muligens ville hevde at dette er aspekt ved - eller kanskje til og med synonymt med? - en beskrivende skrivehandling og derfor hører hjemme i venstre kolonne.

Verbet reflektere har vi, under tvil, plassert i kolonna for verb knyttet til skriveaktiviteten. Ett argument for dette er at det i de fleste tilfellene står integrert som en del av selve skriveoppdraget. Et annet er at reflektere inngår som én av skrivehandlingene i det tidligere nevnte Skrivehjulet

6 Eksempel på verbfraser: gjøre rede for, trekke inn. Eksempel på nominaliseringer: refleksjon, argumentasjon, drøfting. I noen av kategoriseringene har vi også tatt med objektet i parentes - fordi det ellers ville blitt meningsløst: ta utgangspunkt i (læreplan), utvikle (undervisningsopplegg), lage (skisse). 


\section{Ingunn Ofte \& Hildegunn Otnes}

Tabell: Skrivehandlinger og andre handlinger i skriveoppgaven

\begin{tabular}{|c|c|c|c|c|}
\hline & & \multicolumn{2}{|c|}{$\begin{array}{l}\text { Verb i instruksene knyttet } \\
\text { til skriveaktiviteten }\end{array}$} & \multirow{2}{*}{\begin{tabular}{|l|}
\multicolumn{1}{|c}{$\begin{array}{c}\text { Verb } \mathrm{i} \text { instruksene som } \\
\text { angir andre handlinger }\end{array}$} \\
$\begin{array}{l}\text { Kognitive og praktiske handlinger } \\
\text { forut for skrivesituasjonen }\end{array}$ \\
\end{tabular}} \\
\hline \multirow{7}{*}{ 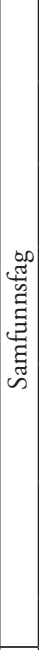 } & & $\begin{array}{l}\text { Verb som angir } \\
\text { skrivehandlinger }\end{array}$ & $\begin{array}{l}\text { Andre verb knyttet til } \\
\text { skrivinga }\end{array}$ & \\
\hline & Oppg. I & Beskrive, drøfte & $\begin{array}{l}\text { Trekke inn (relevant } \\
\text { pensum), peke på }\end{array}$ & \\
\hline & Oppg. 2 & $\begin{array}{l}\text { Diskutere, begrunne, } \\
\text { redegjøre, skrive }\end{array}$ & Gi råd & Ta utgangspunkt i (bestemt fagartikkel) \\
\hline & Oppg. 3 & Fortelle, begrunne & $\begin{array}{l}\text { Presentere (et } \\
\text { undervisningsopplegg) } \\
\text { Avgrense, aktualisere }\end{array}$ & Velge (kompetansemål) \\
\hline & Oppg. 4 & $\begin{array}{l}\text { Formulere, beskrive, } \\
\text { drøfte, skrive }\end{array}$ & $\begin{array}{l}\text { Trekke inn (relevant pensum) } \\
\text { Trekke inn (erfaringer fra } \\
\text { praksis) }\end{array}$ & Ta utgangspunkt i (læreplan) \\
\hline & Oppg. 5 & $\begin{array}{l}\text { Begrunne, reflektere, } \\
\text { formulere, drøfte }\end{array}$ & $\begin{array}{l}\text { Trekke inn (pensum) } \\
\text { Lage (skisse) }\end{array}$ & $\begin{array}{l}\text { Velge (kompetansemål) } \\
\text { Implementere (arbeid med grunnleggende } \\
\text { ferdigheter) }\end{array}$ \\
\hline & Oppg. 6 & Redegjøre, drøfte & & Ta utgangspunkt i (egne erfaringer med faget) \\
\hline \multirow{4}{*}{ 章 } & Oppg. 7 & Diskutere & $\begin{array}{l}\text { Anvende (faglitteratur) } \\
\text { Ta inn (erfaringer fra praksis) }\end{array}$ & \\
\hline & Oppg. 8 & Argumentere, reflektere & $\begin{array}{l}\text { Introdusere, dele, presentere, } \\
\text { trekke inn - (den valgte } \\
\text { romanen) }\end{array}$ & Utvikle (undervisningsopplegg), utforske \\
\hline & Oppg. 9 & $\begin{array}{l}\text { Oppsummere, beskrive, } \\
\text { reflektere }\end{array}$ & Skissere & Velge (pensumlitteratur) \\
\hline & Oppg. Iо & $\begin{array}{l}\text { Gjøre rede for, drøfte, } \\
\text { diskutere }\end{array}$ & $\begin{array}{l}\text { Trekke inn (praktiske } \\
\text { eksempler) }\end{array}$ & Velge (fokusområde) \\
\hline & Oppg. II & Gjøre greie for, drøfte & & \\
\hline \multirow{4}{*}{ 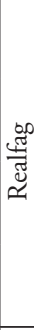 } & Oppg. I2 & $\begin{array}{l}\text { Begrunne, diskutere, } \\
\text { reflektere }\end{array}$ & Belyse & $\begin{array}{l}\text { Velge (kompetansemål som utgangspunkt) } \\
\text { Utvikle (undervisningsopplegg) }\end{array}$ \\
\hline & Oppg. I3 & $\begin{array}{l}\text { Redegjøre, drøfte, } \\
\text { oppsummere }\end{array}$ & $\begin{array}{l}\text { Presentere (et utvalg av } \\
\text { datamaterialet) }\end{array}$ & Utvikle (undervisningsopplegg) \\
\hline & Oppg. I4 & Gjøre rede for & $\begin{array}{l}\text { Trekke inn (relevant } \\
\text { litteratur) }\end{array}$ & $\begin{array}{l}\text { Velge (problemstilling) } \\
\text { Ta utgangspunkt i (undervisningopplegg) }\end{array}$ \\
\hline & Oppg. I5 & $\begin{array}{l}\text { Begrunne, beskrive, } \\
\text { reflektere }\end{array}$ & & $\begin{array}{l}\text { Ta utgangspunkt i (grunnleggende ferdighet) } \\
\text { Utvikle (undervisningsopplegg) }\end{array}$ \\
\hline \multirow{4}{*}{ 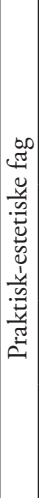 } & Oppg. I6 & $\begin{array}{l}\text { Beskrive, begrunne, } \\
\text { drøfte, reflektere }\end{array}$ & Vise & $\begin{array}{l}\text { Velge (tema) } \\
\text { Utvikle (eget prosjekt) } \\
\text { Tilpasse (materialer, redskaper og teknikker) } \\
\text { Organisere (en undervisningssituasjon) } \\
\text { Tilrettelegge }\end{array}$ \\
\hline & Oppg. I7 & $\begin{array}{l}\text { Beskrive, forklare, } \\
\text { begrunne, tolke, } \\
\text { oppsummere, vurdere }\end{array}$ & & $\begin{array}{l}\text { Utvikle (eget undervisningsopplegg) } \\
\text { Observere (elever) }\end{array}$ \\
\hline & Oppg. I8 & Drøfte, skrive & $\begin{array}{l}\text { Lage (skisse) } \\
\text { Analyse }\end{array}$ & Velge (tema) \\
\hline & Oppg. I9 & Grunngi & $\begin{array}{l}\text { Relatere til (lærestoff), } \\
\text { presentere (et metodisk } \\
\text { opplegg), vise }\end{array}$ & $\begin{array}{l}\text { Velge (sang, låt eller dans) } \\
\text { Ta utgangspunkt i (et undervisningsopplegg) }\end{array}$ \\
\hline
\end{tabular}


(Berge et al., 20I6). Det kan imidlertid problematiseres hvor eksplisitt denne skrivehandlinga egentlig er: For det første kan man diskutere om det er mulig å si hva som kjennetegner denne skrivemåten (jf. Dagsland, 20I8), og for det andre kan man stille spørsmål om dette egentlig er en skrivehandling, eller om det snarere er en kognitiv handling. Muligens er det nyanseforskjeller mellom de ulike refleksjonsoppdragene, som burde medføre at verbet reflektere kunne plasseres i ulike kolonner i tabellen, avhengig av hva refleksjonen omfatter (se analysedel 3 ).

Det kan videre diskuteres om de andre verbene knyttet til skriveaktiviteten (kolonne 2) i instruksene er til hjelp eller forvirring. Verbene som er brukt her, er i en del tilfeller trolig ment som en utdyping eller operasjonalisering av skrivehandlinga; f.eks. instruerer flere oppgaveformuleringer om at studenten må anvende eller trekke inn faglitteratur når han skal drofte en problemstilling. Andre ganger kan imidlertid bruken av slike mindre eksplisitte skrivehandlingsverb bidra til å gjøre det utfordrende for studentene å se tydelig hva slags type skriving som egentlig er forventet av dem. Blant annet kan man spørre seg hvordan handlinger som vise og dele skal manifesteres skriftlig: ${ }^{7}$

Oppg. 16: Vis hvordan [undervisnings] opplegget ivaretar kompetansemålene, grunnleggende ferdigheter og tilpasset opplæring, jfr. Kunnskapsløftet, Ko6.

Oppg. 8: $\quad$... share some brief background information with your target learners.

Et vanlig forløp i en akademisk skriveprosess er at man først skal beskrive eller gjøre rede for et felt eller tema, før man så mer inngående skal drøfteldiskutere et avgrenset problem knyttet til temaet. Det kan trolig hevdes at man beveger seg opp på et mer abstrakt/akademisk nivå når man går over til å drøfte. Denne kombinasjonen er til stede i mange av våre oppgaver og ofte i denne rekkefølgen:

Oppg. Io: Gjør rede for synet på språk i læreplanen for norsk og $\boldsymbol{d} \boldsymbol{r} \boldsymbol{f} \boldsymbol{f} \boldsymbol{t}$ dette opp mot teoretiske perspektiv i faglitteraturen du har lest.

Dette indikerer noe om hvilke ferdigheter faglærerne vektlegger i disse oppgavene. Slike oppgaveformuleringer gir også en pekepinn om hvordan studentene kan kombinere skrivehandlinger og bygge opp et akademisk, fagdidaktisk resonnement fra det enkle til det mer avanserte.

Del 2: Andre handlinger

Tabellen viser at I6 av I9 oppgaver også inneholder instrukser som indikerer andre handlinger studentene skal utføre i forbindelse med gjennomføringa av oppgaven (jf. høyre kolonne i tabellen). Verbene brukt i disse instruksene omfatter en blanding av praktiske handlinger og noen mer kognitive handlinger knyttet til undervisning. De er dessuten i stor grad handlinger som studenten skal ha utført før selve skriveaktiviteten, for eksempel skal de utvikle og gjennomfore et undervisningsopplegg, og bruke dette som utgangspunkt for selve skrivinga. Nedenfor viser vi eksempler på noen av verbene fra høyre kolonne i sin språklige kontekst.

Oppg. I4: Du skal ta utgangspunkt $\boldsymbol{i}$ et erfart eller tenkt konkret undervisningsopplegg.

Oppg. 5: Du skal implementere arbeid med en (eller flere) av læreplanens grunnleggende ferdigheter som en del av undervisningsopplegget ditt.

\footnotetext{
7 Artikkelforfatterne har valgt å sette verbene i eksemplene i fet skrift.
} 
En annen type handlinger innebærer at studenten skal ta valg forut for skrivinga, for eksempel velge tema eller pensumlitteratur for teksten de skal skrive. I de fleste tilfellene er det snakk om didaktiske valg og vurderinger av ulike slag; av kompetansemål, undervisningsmateriell, design av undervisningsopplegg og så videre. Verbet velge forekommer i ni av oppgavene. Vi finner at dette er et verb som kan variere når det gjelder mengde og kompleksitet på det som skal velges: om det for eksempel er en sang eller et kompetansemål; om studentene får alternativer de kan velge fra, eller om de skal ta et valg basert på faglig kunnskap:

Oppg. 9: Choose one of the following three chapters from Hedge's Teaching and Learning in the Classroom set for this semester: [alternativer presenteres].

Oppg. Iо: Vel ut eit av hovudmåla i det norske dialektlandskapet ...

I oppgave 9 gir faglæreren studenten muligheten til å velge utgangspunkt for diskusjonen, men det er faglæreren som bestemmer hvilke alternativer studenten får velge fra. Dette kan dermed sies å være et enklere valg, siden det baseres på gitte alternativer og fordi det kan gjøres uten å ha noen forkunnskaper om emnet. I oppgave Io, derimot, må studenten selv ha oversikt over de ulike hovedområdene i det norske dialektlandskapet for å kunne ta et valg.

Flere av verbene vi har plassert i høyre kolonne i tabellen, er praktiske handlinger knyttet til undervisning og planlegging av denne: lage, gjennomfore, utvikle, organisere, tilrettelegge og observere. Vi merker oss at utvikle går igjen flere ganger i vårt materiale. Dette er et verb som framhever noe prosessuelt og skapende og som får fram en større kompleksitet enn for eksempel verbet lage. Blant medlemmer av lærerstanden kan det ganske sikkert hevdes at det å lage (planlegge, organisere, utvikle) et velfungerende undervisningsopplegg krever høy kompetanse og kreativitet. Likevel er det nok ofte innenfor akademia slik at det først er når man klarer å reflektere over hvorfor det er velfungerende - og særlig når dette gjøres skriftlig - at man har nådd høyt opp i kompetansetaksonomien.

Del 3: Å reflektere

Seks av oppgavetekstene gir studenten i oppgave å reflektere over noe. Dette er et verb som er mye brukt i lærerutdanning, og blant annet Korthagen \& Vasalos (2005) vektlegger viktigheten av refleksjon «in promoting sound professional behaviour» (s. 48). Det har som nevnt vært diskutert i flere sammenhenger hva det innebærer å reflektere (Dagsland, 20I8; Grüters, 20II; Korthagen, 20I4; Søndenå, 2002). Flere av definisjonene omfatter det å tenke - over erfaringer, over praksis, over noe man har gjort. Dysthe et al. (2000) beskriver refleksjon som den «aktiviteten som er knyttet til ettertanke og tilbakeblikk» (s. 7I). Dette stemmer overens med flere av tilfellene i vårt oppgavemateriale, der det spørres etter studentens opplevelse og studentens rolle som lærer:

Oppg. 13: Her skal dere også reflektere kort over deres opplevelse av arbeidet med oppdraget.

Oppg. 15: Reflekter over hvilken betydning din rolle som lærer kan ha for elevenes arbeid og læring i denne timen.

Her er det altså snakk om subjektive, erfaringsbaserte refleksjoner. De skal gjerne være knyttet til faglig kunnskap, men det primære er at de er praksisrelaterte (profesjonsrelaterte). Som nevnt i delkapitlet «Tidligere forskning», kan en slik refleksjon ofte bli overflatisk, kanskje 
innforstått, og kun gjengi hendelsesforløp - og dermed anses som en enkel, og kanskje mindre akademisk, handling. Har studenten i tillegg et metaperspektiv på det som har foregått og et fokus på underliggende faktorer (kontekstuelle rammer, personlige egenskaper osv.), kan det imidlertid bli en mer dyptpløyende refleksjon (jf. Korthagen, 20I4). Det kan hevdes at man beveger seg på et mer avansert nivå, der man forsøker å forstå de ulike sammenhengene i handlingsforløpet. John Biggs og Catherine Tang (2007) snakker blant annet om ulike "performances of understanding» (s. 86). De fleste refleksjonsinstruksene i vårt materiale åpner for denne typen refleksjon.

Sjøberg (200I) og andre forskere vektlegger at refleksjon er en måte å bygge bro mellom teori og praksis på. Noen av oppgaveformuleringene i vårt materiale får også fram dette aspektet:

Oppg. 8: $\quad$.. argue for and reflect on your presented ideas by drawing on background sources on your reading list.

Oppg. 5: Begrunn og reflekter over valg av undervisningsmetoder/arbeidsmetoder i forhold til relevant teori.

Disse instruksene ber studentene om å anvende teori/faglitteratur i sine refleksjoner, og det knyttes sammen med verb som «argumentere» (argue) og «begrunne». Her inviteres det til et nytt abstraksjonsnivå, et nivå med større kompleksitet som krever kombinasjonsevne og analytisk kompetanse. Ifølge Alvesson og Sköldberg (20I8) er det denne type refleksjon som er ønskelig i en akademisk kontekst.

Vi ser altså av materialet vårt at handlinga å reflektere kan ligge på flere nivå i et akademisk handlingshierarki, avhengig av konteksten eller faglærerens forestilling om hva refleksjon er. Dette viser dermed at noen verb er mer «ambiguous and fluid» (Brabrand \& Dahl, 2009, s. 546). Det er i den forbindelse også relevant å se verbet reflektere opp mot verbet drofte (ev. diskutere). Noen av oppgavedesignerne i vårt materiale bruker drofte der andre muligens ville valgt å bruke reflektere og vice versa. I noen tilfeller brukes drøfte i de sammenhenger hvor det er rent teoretiske, faglige, abstrakte temaer som diskuteres, og der det gjerne er krav til referanser (jf. eksempler nedenfor). I oppgave 5 er begge verb brukt, og det antydes slik trolig en progresjon fra begrunnelse/refleksjon til drøfting. Vårt materiale sier imidlertid ingenting tydelig om det er slik at det ene verbet er høyere på den akademiske rangstigen enn den andre.

Oppg. 13: Observasjonene skal drøftes ved å bruke litteraturen vi har jobbet med i faget og eventuelt annen relevant litteratur.

Oppg. 2: $\quad$ Ta så utgangspunkt i artikkelen til Anker \& von der Lippe (2003) og diskuter hvordan skolene/lærerne kunne ha håndtert terrorhandlingen på en bedre måte.

Oppg. 5: Begrunn og reflekter over valg av undervisningsmetoder/arbeidsmetoder i forhold til relevant teori. Formuler en problemstilling til planen din. Drøft problemstillingen med vekt på begrunnelser og erfaringer (egen praksiserfaring), fagdidaktisk teori og læreplanen.

Vi har tidligere stilt spørsmålet om hvor i tabellen verbet reflektere burde plasseres. I enkelte tilfeller er refleksjonen en kognitiv aktivitet som primært skal foregå i en praksissituasjon for skrivearbeidet. Vi har altså likevel valgt å plassere alle forekomstene i kolonna for skrivehandlinger, men håper at eksemplene er lagt fram så transparent at den enkelte leser selv kan vurdere. 


\section{NOEN HOVEDTENDENSER - EN OPPSUMMERENDE DRØFTING}

I denne studien har vi retta oppmerksomheten mot ulike handlinger som fagdidaktikere mener det er viktig å mestre i lærerprofesjonen, og som de derfor inviterer sine studenter til å utføre i forbindelse med akademiske skriveoppgaver. Dette handlingsperspektivet innebærer at vi har retta oppmerksomheten mot en sentral ordklasse, nemlig verb, i våre analyser av oppgavetekstene. Analysekategoriene vi benytter i kartlegginga av de ulike handlingene må ikke forstås som absolutte rettesnorer, men som redskaper for sammenlikninga av handlingene. Vi understreker at det ikke er vanntette skott mellom de ulike kategoriene i tabellen i delanalyse $\mathrm{I}$. Ved å presentere alle verbene fra materialet i tabellen - mange av dem også gjengitt i sin språklige kontekst har vi forsøkt å gjøre analysene så transparente som mulig. Mange av handlingene er generelle akademiske handlinger, mens andre trolig er mer spesifikt knyttet til fagdidaktikken. I det følgende vil vi rette oppmerksomheten mot noen utvalgte tendenser i materialet.

\section{Tydelighet og kompleksitet}

Materialet vårt viser at det er forskjell på antall handlinger som nevnes i de ulike oppgavene, og at det varierer hvor instruksene om selve skrivehandlingene er plassert i oppgaveteksten. Videre viser materialet at det ikke er noen konsensus blant faglærerne når det gjelder hvor mye, eller hva slags, informasjon en oppgavetekst skal inneholde.

Analysen vår antyder ellers at grad av tydelighet - eller mangel på tydelighet - i skriveoppgavene er et sentralt aspekt i oppgavedesign. Andre studier har også pekt på dette momentet som og en viktig faktor og utfordring (Otnes, 20I4). Skriveinstruksene er ikke like eksplisitte i alle skriveoppgavene i vårt materiale, og får dermed ikke alltid like tydelig fram hvilke skrivehandlinger de legger opp til. Utydelighet i skriveinstruksene gir seg uttrykk på ulike måter, blant annet ved hvor de er plassert i oppgaven og ved hvilke verb som er brukt. Slike typer utydelighet kan gjøre det utfordrende for studentene å besvare oppgaven og se hvilke handlinger som er viktigst.

Flere av oppgavene i materialet vårt preges imidlertid av at de faktisk er tydelige. De klarer å framheve de viktigste instruksene på en eksplisitt måte - blant annet hva det er som skal skrives og hvordan - ved hjelp av entydig formulerte instrukser og/eller grafiske markeringer.

\section{Den utfordrende refleksjonen}

Et annet funn i denne studien, som støtter opp om det andre studier før oss har funnet (Klemp, 20I3; Schön, I990; Søndenå, 2002), er at handlinga reflektere står sterkt i lærerutdanningskonteksten, men at begrepet brukes med litt ulike betydninger avhengig av oppgavens formål og av oppgavedesignerens forestilling om begrepet. Vi har funnet at dette verbet i vårt materiale ofte brukes om en erfaringsbasert og til dels subjektiv tenking (kognitiv handling), og at det primært er knyttet til reelle erfaringer i en undervisningssituasjon. Refleksjonen kan være fundert i faglige, kunnskapsbaserte resonnement, men den trenger ikke nødvendigvis være teoretisk fundert (i betydningen henvisning til faglitteratur). Det varierer i våre oppgaveeksempler hvor dyptpløyende og grundig den skal være (jf. Korthagen, 20I4), og om refleksjonen primært skal trekke inn kontekstuelle faktorer i den konkrete situasjonen - eller om den også skal trekke inn fagteori.

Refleksjon er altså en handling som er typisk for profesjonsutdanninger. Vi spør oss imidlertid om det kan være slik at fordi den i stor grad er knyttet til praksis, kanskje ikke har samme status som andre handlinger i hierarkiet av akademiske handlinger (f.eks. drøfte). Samtidig kan dette variere avhengig av forståelsen av refleksjon (Alvesson \& Sköldberg, 20I8). Her ligger 
kanskje noe av lærerutdanneres dilemma, både når det gjelder design av fagdidaktiske skriveoppgaver og vurdering av studentenes besvarelser i etterkant. Det har i våre analyser også framkommet at refleksjon ofte er noe man skal gjøre for man skriver, og slik sett i en del tilfeller ikke skulle vært rubrisert som skrivehandling, men snarere under «andre handlinger». Dessuten er det, som nevnt tidligere, heller ikke innlysende hvordan man skriver reflekterende (jf. Dagsland, 20I8). Det er med andre ord fortsatt flere spørsmål knyttet til refleksjon som kan være relevant å diskutere videre i lærerutdanningsmiljøer.

\section{Profesjonsoppgaver i akademia}

Det er mange valg og vurderinger en oppgavedesigner må gjennom. I en lærerutdanningskontekst kommer blant annet vurderinger rundt hvordan man best skal gi oppgaven en fagdidaktisk vinkling. Alle oppgavene vi har analysert, er knyttet til det profesjonsfaglige og til praksisfeltet, noe som kjennetegner fagdidaktiske oppgaver. Selv om det i vårt materiale er visse forskjeller mellom oppgavene, så har vi ikke kunnet påvise store forskjeller mellom fag når det gjelder å designe oppgaver. Den viktigste grunnen, mener vi, er at dette ikke er fagoppgaver, men fagdidaktikkoppgaver. Som vi gjorde rede for under teoretiske perspektiver, er fagdidaktikk en fellesbetegnelse for profesjonsretta kompetanse i alle fag der det handler om å bygge en bro mellom faglig innhold og pedagogisk refleksjon og å treffe begrunnede valg (Sjøberg, 200I).

Som tidligere nevnt, inviterer alle oppgavene til generelle akademiske handlinger - skrivehandlinger som beskrive eller gjøre rede for og drøfte eller begrunne. De sier alle også noe om at fagdidaktisk teori skal innlemmes. Videre er alle oppgavene knyttet til det profesjonsfaglige ved læreryrket, og vi ser at praktiske handlinger som planlegge og utvikle så vel som mer kognitive handlinger som velge og reflektere utgjør en sentral del av det mer spesifikt fagdidaktiske handlingsrepertoaret. Studentene må gjøre valg basert på faglig kunnskap, og de må skissere praktiske opplegg for undervisning - og så bruke dette som utgangspunkt for refleksjoner og/eller drøftinger i skrivearbeidet. Det varierer imidlertid mellom oppgavene i materialet hvor stor plass denne praktiske delen utgjør i fagdidaktikkoppdraget. Enkelte oppgaver inneholder flere delinstrukser knyttet til dette, og det praktiske arbeidet må i noen tilfeller reelt gjennomføres. Seks av oppgavene skiller seg fra de andre ved at de har mindre vektlegging av konkrete klasseromsaktiviteter: Det teoretiske og akademiske skrivearbeidet har fokus, og praksiseksemplene skal bare trekkes inn for å belyse det teoretiske (for eks. oppg. 7 og Io) eller man skal drøfte det teoretiske temaets relevans for skolefaget (oppg. I). Det profesjonsfaglige og fagdidaktiske ivaretas altså på ulike måter i oppgavene, og er ikke nødvendigvis knyttet til et konkret undervisningsopplegg.

\section{KONKLUSJON}

Gjennom denne studien har vi hatt som intensjon å bidra til økt bevissthet rundt, og tverrfaglig diskusjon om, hvilke handlingsinstrukser som inngår i et utvalg fagdidaktiske skriveoppgaver i lærerutdanninga. Alle instruksene inneholder både skrivehandlinger og andre handlinger knyttet til lærerprofesjonen. Vi finner også at det er ulik praksis mellom faglærerne når det gjelder hvor mye og hva slags informasjon en oppgavetekst skal inneholde. Vi mener derfor at design av skriveoppgaver bør inngå som et sentralt tema i det praksisfellesskapet som lærerutdanning utgjør. Her vil vi hevde at det er aktuelt å diskutere hvilke handlinger studentene bes om å utføre - og blant annet rette søkelyset mot hvilke skrivehandlinger som skal vektlegges i en akademisk skriveoppgave i lærerutdanninga og en felles forståelse av hva disse innebærer (jf. Beck \& Jeffrey, 2007; Stock \& Eik-Nes, 2019). 


\section{Ingunn Ofte \& Hildegunn Otnes}

Materialet er lite og derfor ikke generaliserbart, og vi har avgrenset oss til å se på oppgaveformuleringer uten annen informasjon om skrivesituasjonene. Ved å intervjue henholdsvis faglærerne (oppgavedesignerne) og studentene kunne man for eksempel få klarhet i om oppgaveordlyden fikk fram det som var intendert, og om studentene har hatt nok modellering og undervisning i hva som forventes innenfor de ulike skrivehandlingene. Vi mener imidlertid at også en avgrenset tekststudie som denne, der oppgavetekstene analyseres slik de står på papiret, og uten kontekstdata, kan avdekke betydningen av presise, strukturerte og gjennomtenkte oppgaveformuleringer og handlingsinstrukser. Vi mener også at vi med vår studie har bidratt til å få fram hvor sentrale verbene er i slike fagdidaktiske skriveoppdrag til studenter.

\section{FORFATTERPRESENTASJON}

Ingunn Ofte er stipendiat og universitetslektor i engelskdidaktikk ved Institutt for lærerutdanning, NTNU. Doktorgradsprosjektet omhandler akademiske skriveundervisningspraksiser i lærerutdanninga. Hun har også forsket på lærerstudenters akademiske skrivekompetanse, især bruk av hverandreveiledning i denne sammenhengen, i tillegg til lærere og elevers bruk av norsk i engelskundervisninga i grunnskolen. Hun har undervisningserfaring fra ungdomsskole og videregående skole, samt på bachelor- og masternivå i lærerutdanninga.

Hildegunn Otnes er professor i norskdidaktikk ved Institutt for lærerutdanning, NTNU. Fagfeltene hennes er samtaleanalyse, anvendt grammatikk og skrivedidaktikk. Hun har deltatt i flere prosjekter om skriving i grunnskole og lærerutdanning, og også vært medforfatter til artikler og bøker om emnet, bl.a. Å invitere elever til skriving - ulike perspektiver på skriveoppgaver (2015) og Nye grep om skriveopplaringa (202I).

\section{REFERANSER}

Alvesson, M. \& Sköldberg. K. (2018). Reflexive methodology. New vistas for qualitative research. Sage Publications.

Arneback, E., Englund, R. \& Solbrekke, T. D. (2017). Student teachers' experiences of academic writing in teacher education - on moving between different disciplines. Education Inquiry, 8(4), 268-283. https://doi.org/10.1080/20004508.2017.1389226

Beck, S. W. \& Jeffery, J. V. (2007). Genres of high-stakes writing assessments and the construct of writing competence. Assessing Writing, 12(1), 60-79. https://doi.org/10.1016/j.asw.2007.05.001

Berge, K. L., Evensen, L. S. \& Thygesen, R. (2016). The wheel of writing: A model of the writing domain for the teaching and assessing of writing as a key competency. The Curriculum Journal, 27(2), 172-189. https://doi.org/10.1080/09585176.2015.1129980

Biggs, J. \& Tang, C. (2011). Teaching for quality learning at university: What the student does. McGraw-Hill and Open University Press.

Brabrand, C. \& Dahl, B. (2009). Using the SOLO taxonomy to analyze competence progression of university science curricula. Higher Education, 58(4), 531-549. https://doi.org/10.1007/s10734-0099210-4

Brossell, G. (1983). Rhetorical specification in essay examination topics. College English, 45(2), 165-173. https://doi.org/10.2307/377224

Cremin, T. \& Myhill, D. (2012). Writing voices. Creating communities of writers. Routledge.

Dagsland, S. (2018). Om å jakte på heffalomper: Et metalingvistisk perspektiv på antatt reflekterende og antatt utforskende skriving $i$ norsk og matematikk [Doktorgradsavhandling, Norges teknisknaturvitenskapelige universitet]. NTNU Open. http://hdl.handle.net/11250/2494191

Dysthe, O., Hertzberg, F. \& Hoel, T. L. (2000). Skrive for à lare skriving i høyere utdanning. Abstrakt forlag.

Erixon, P. O. \& Josephson, O. (Red.). (2017). Kampen om texten. Examensarbetet i lärarutbildningen. Studentlitteratur. 
French, A. (2018). 'Fail better': Reconsidering the role of struggle and failure in academic writing development in higher education. Innovations in Education and Teaching International, 55(4), 408-416. https://doi.org/10.1080/14703297.2016.1251848

Greek, M. \& Jonsmoen, K. M. (2016). Hvilken tekstkyndighet har studenter med seg fra videregående skole? Uniped, 39(3), 255-271. https://doi.org/10.18261/issn.1893-8981-2016-03-06

Grüters, R. (2011). Refleksjon $i$ blogg. En hermeneutisk studie av refleksjon og dens tekstlige og retoriske manifestasjoner $i$ en ny type skrive- og arkiveringsteknologi [Doktorgradsavhandling, Norges teknisknaturvitenskapelige institutt]. NTNU Open. http://hdl.handle.net/11250/244000

Hellekjær, G. O. (2005). The acid test: Does upper secondary EFL instruction effectively prepare Norwegian students for the reading of English textbooks at colleges and universities? [Doktorgradsavhandling, Universitetet i Oslo]. DUO vitenarkiv. http://urn.nb.no/URN:NBN:no-11346

Hendricks, M. \& Quinn, L. (2000). Teaching referencing as an introduction to epistemological empowerment. Teaching in Higher Education, 5(4), 447-457.

Hertzberg, F. (1999). Å didaktisere et fag - hva er det? I C. Nyström \& M. Ohlsson (Red.), Svenska på prov. Arton artiklar om språk, litteratur, didaktikk och prov. En vänskrift till Birgitta Garme på 60-års dagen den 24. november 1999. Uppsala Universitet.

Ivanič, R. (1998). Writing and identity. The discoursal construction of identity in academic writing. John Benjamins Publishing Company.

Ivanič, R. (2004). Discourses of writing and learning to write. Language and Education, 18(3), 220-243. https://doi.org/10.1080/09500780408666877

Johnsen, E. B. (1997). Oppgavetekst og dannelse. Artiumsstilens emner, formuleringer og forvaltning 1888-1991. Acta Humaniora, 6.

Klemp, T. (2013). Refleksjon - hva er det, og hvilken betydning har den i utdanning til profesjonell lærerpraksis? Uniped, 36(1), 42-58. http://dx.doi.org/10.3402/uniped.v36i1.20957

Korthagen, F. A. J. (2014). Promoting core reflection in teacher education: Deepening professional growth. I L. Orland-Barak \& C. J. Craig (Red.), International teacher education: Promising pedagogies (Part A) (s. 73-89). Emerald.

Korthagen, F. A. J. \& Vasalos, A. (2005). Levels in reflection. Core reflection as a means to promote professional growth. Teachers and Teaching: Theory and Practice, 11(1), 47-71. https://doi. org/10.1080/1354060042000337093

Kroll, B. \& Reid, J. (1994). Guidelines for designing writing prompts: Clarifications, caveats and cautions. Journal of Second Language Writing, 3(3), 231-255. https://doi.org/10.1016/1060-3743(94)90018-3

Kvistad, A. \& Otnes, H. (2019). Mottakerinstansen i skoleskriving - en studie av skriveoppgaver fra Normprosjektet. Nordic Journal of Literacy Research, 5(2), 100-119. https://doi.org/10.23865/njlr. v5.1644

Lea, M. R. \& Street, B. V. (2000). Student writing and staff feedback in higher education: An academic literacies approach. I M. R. Lea \& B. Stierer (Red.), Student writing in higher education. New Contexts (s. 32-46). Open University Press.

Liu, F. \& Stapleton, P. (2015). Writing prompt convergence in high-stakes tests: Exploring rhetorical functions and objects of enquiry. Studies in Educational Evaluation, 47, 68-75. https://doi.org/10.1016/ j.stueduc.2015.09.001

Liu, F. \& Stapleton, P. (2018). Connecting writing assessment with critical thinking: An exploratory study of alternative rhetorical functions and objects of enquiry in writing prompts. Assessing Writing, 28, 10-20. https://doi.org/10.1016/j.asw.2018.09.001

Lorentzen, S., Streitlien, Å., Tarrou, A. L. H. \& Aase, L. (1998). Fagdidaktikk - innføring i fagdidaktikkens forutsetninger og utvikling. Universitetsforlaget.

Matre, S., Otnes, H. \& Solheim, R. (2021). Nye grep om skriveopplaringa. Forskningsfunn og praksiserfaringar. Universitetsforlaget.

Ongstad, S. (1997). Sjanger, posisjonering og oppgaveideologier: et teoretisk-empirisk bidrag til et tverrfaglig, semiotisk og didaktisk sjangerbegrep. Et teoretisk-empirisk bidrag til et tverrfaglig, semiotisk og didaktisk sjangerbegrep [Doktorgradsavhandling]. Norges teknisk-naturvitenskapelige universitet. 


\section{Ingunn Ofte \& Hildegunn Otnes}

Otnes, H. (2014). Å designe skriveoppgaver. I A. J. Aasen \& A. Skaftun (Red.), Skriv! Les! 2: Artikler fra den andre nordiske konferansen om skriving, lesing og literacy (s. 237-256). Akademika forlag.

Otnes, H. (2015). Skriveoppgaver under lupen. I H. Otnes (Red.), A invitere elever til skriving. Ulike perspektiver på skriveoppgaver, (s. 11-27). Fagbokforlaget.

Schön, D. A. (Red.). (1990). The reflective turn: Case studies in and on educational practice. Teachers College Press.

Sjøberg, S. (2001). Innledning: Skole, kunnskap, fag. I S. Sjøberg (Red.), Fagdebatikk: fagdidaktisk innforing i sentrale skolefag. Gyldendal Akademisk.

Stock, I. \& Eik-Nes, N. (2019). Writing acts in bachelor theses. What do they reveal about the genre? I Stock, I. (2019). Faglig stemme i akademisk skriving. En kvalitativ undersøkelse av skrivehandlinger og kildebruk i bacheloroppgaver [Doktorgradsavhandling, Norges teknisk-naturvitenskapelige universitet]. NTNU Open. http://hdl.handle.net/11250/2628607

Søndenå, K. (2002). Tradisjon og Transcendens - ein fenomenologisk studie av refleksjon i norsk forskulararutdanning [Doktorgradsavhandling]. Gøteborgs Universitet.

Troelsen, S. (2018). En invitation man ikke kan afslå - analyse af afgangsprøven i skriftlig fremstilling med særligt fokus på skriveordren. Nordic Journal of Literacy Research, 4(1), 142-166. https://doi. org/10.23865/njlr.v4.1267

Vähäpassi, A. (1988). The domain of school writing and development of the writing tasks. I T. P. Gorman, A. C. Purves \& R. E. Degenhart (Red.). The IEA study of written composition 1: The international writing tasks and scoring scales (s. 15-40). Pergamon Press.

Wenger, E. (1998). Communities of practice. Learning, meaning, and identity. Cambridge University Press. 